\title{
IMPACT OF ABUSIVE SUPERVISION ON INTERPERSONAL CONFLICT; MEDIATING ROLE OF BREACH OF PSYCHOLOGICAL CONTRACT AND MODERATING ROLE OF LOCUS OF CONTROL
}

\author{
SAIMA ASHRAF \\ NAILA ASHRAF \\ Capital University of Science and Technology, Islamabad, Pakistan
}

\begin{abstract}
The purpose of this study was to examine the impact of abusive supervision on the interpersonal conflict among teachers in the education sector of Pakistan. The study also explores the mediating role of breach of psychological contract and moderating role of locus of control in the proposed model. The survey was conducted on the teachers of different schools, colleges, and universities of Rawalpindi, Islamabad, Karachi and Lahore. Data was collected from 272 teachers using questionnaires. Results indicated that abusive supervision is positively associated with the interpersonal conflict. Moreover,locus of control acts as a strong moderator on the relationship of abusive supervision and interpersonal conflict such that it weakens the relationship. However, breach of psychological contract didn't mediate the relationship of abusive supervision and interpersonal conflict.
\end{abstract}

\section{INTRODUCTION}

Words of renowned author Wayne Dyer "Conflict cannot survive without your participation" holds true in most of today's organizations. The history of conflict is as old as the history of man itself. People are different in their mental schema, thoughts, opinions and goals, therefore conflicts become inevitable.Conflict refers to some kind of friction or disagreement arising when the beliefs or actions of one or more members of the group are either opposed or unacceptable to one or more members of another group. Conflict is an integral part of human relations, and therefore it has remained a long-standing focus of organizational and team research (Pondy 1967; Jehn \& Mannix, 2001). It is the process that begins when one party perceives that the other party has negatively affected, or will negatively affect something that he or she cares about (Thomas, 1992).

One of the important causes of conflict is abusive supervision. According to the survey in US, abusive supervision affects $13.6 \%$ US workers (Tepper, 2000). Two decades ago, according to the estimation of Leymann (1990) the cost of each incident of abusive behavior in workplace was between $\$ 30,000$ and $\$ 100,000$ annually. The harsh behavior of managers with their subordinates give rise to anarchy at work place, so the exchange of harsh behavior from manager to supervisor and then from supervisor to subordinates causes serious troubles to the lower level employees (Wayne, Hoobler,
Marinova,\& Johnson, 2008). Abusive supervision is the result of external conditions, while others suggest that internal factors are responsible for negative outcomes (e.g.,Harvey \&Martinko, 2008).

Interpersonalconflictarisesduetoabusivesupervision as it is a communicative threatening situation aimed to damage an individual physically or mentally (Leymann, 1990), and it ranges from employees to teams to organizations (Baillien, Neyens, De Witte,\& De Cuyper, 2009).Studies frequently discuss the abusive supervision as a source of interpersonal conflict (Baillien et al., 2009; Jehn, 1995; De Dreu\&Weingart, 2003; Jehn\&Mannix, 2001). Many researchers (Kotlyar\&Karakowsky, 2006; Skogstad, Torsheim, Einarsen, \&Hauge, 2011) focused that inappropriate leadership style result in interpersonal conflict. In interpersonal conflict, two parties are involved of approximately equal strength (usually at peer level), and show non-verbal, verbal behaviors and/or physical assault (McKenna, Smith, Poole \& Coverdale, 2003).

Psychological contract has been widely discussed after 1980s.Literature says that breach is characterized by at least one of five kinds: delay, magnitude, type, inequity (i.e. perceived discrimination), and reciprocal imbalance. It takes place when the output is different from what was expected (Cassar \& Briner, 2011). Apart from this, if the factors like complexity, diversity and globalization prevails in the organizations, it causes not only the psychological breach but it also decreases the affective commitment of the employees with the 
organization (Bao, Olson, Parayitam \& Zhao, 2011).

The term "Locus of Control" was developed by Rotter (1971) as part of social learning theory which states that the relations of employees with their environment is a function of comprehensive learning based on their past experience and expectations from the future (Amram \& Benbenishty, 2014). Locus of control refers to a person's beliefs about control over life events. According to the literature, people are of two kinds. The kind of people who feel themselves responsible for the things are known as internals and those who feel that their outcomes in life are based on external factors like fate, luck and other people etc., which are beyond their control, are known as externals (Findley \& Cooper,1983).

The social exchange theory explains that the supervisor and employee's relationship is based on reciprocal treatment. When the supervisor treats the employees in abusive way, the employees will also respond in the form of deviant behavior, and this will ultimately spoil the interpersonal relationship (supervisor-employee). Due to social exchange, employees have some expectations from their supervisors, and they form a certainkind of psychological contract with their organization, but when they perceive that their expectations are not being fulfilled by the employer, then breach of psychological contract occurs (Morrison \& Robinson, 1995). So, organizational members have a social exchange relationship not only with other members of the organization, but also with the organization.

The abusive supervision in education sector of Pakistan needs to be addressed at earliest as it negatively harms the overall workplace environment, and create hurdles in achieving the basic objectives of the institute. This study will help the education sector in understanding the fact that abusive supervision is not a type of issue which can be ignored. Pakistani culture is power distant culture where power is mostly concentrated at the top level and the decisions are usually taken by the higher authority in the hierarchy. Similarly, in educational institutes, the teachers are not permitted to make the decisions on their own, that binds them to follow the orders only, rather than to take some innovative steps for the betterment of the organizations.

\section{LITERATURE REVIEW}

\section{Abusive Supervision and Interpersonal Conflict}

The emerging literature explores abusive supervision as rude, offensive, and unfair behavior of supervisors towards their subordinates (Leymann, 1992). Abusive supervision has a negative impact on various organizational outcomes, e.g., job satisfaction
(Tepper, Duffy, Hoobler, \& Ensley, 2004), organizational citizenship behaviours (Zellars, Tepper, \& Duffy, 2002), job performance (Aryee, Sun, Chen, \&Debrah, 2008), loyalty (Aryee, Chen, Sun, \&Debrah, 2007), and it enhances work place deviance (Tepper et al., 2009), and psychological distress (Tepper, 2000).

Abuse results in lower morale, lower motivation, increased turnover, increased sick leaves and diminishing creativity, etc. All these outcomes result in poor interpersonal relationships (Johnson \&Indvik, 2001). If the supervisor fails to show optimism and consider the employee as an easy target for mistreatment, then the management should take responsibility to help its employees by addressing abusive supervision prevailing in the workplace (Harvey, Stoner, Hochwarter\&Kacmar, 2007).Sometimes, minor acts of disrespect and rudeness and their reactions are simple reasons, why many employees don't like their organizations, don't respect their coworkers and wish they were not there (Johnson \&Indvik, 2001).

Conflict is a dynamic process that occurs between parties as they experience negative emotional reactions to perceived disagreements and interference with the achievement of their goals (Barki\&Hartwick, 2004). The interpersonal conflict is the process in which a person is systematically subjected to aggressive behavior from one or more colleagues or supervisors over a long period of time (Einarsen, 1999). In this situation, it is difficult for the victim to escape or defend himself and this ultimately results in severe psychological trauma. Leymann and Gustafson (1996) consider it an incremental process which is marked with aggressive act and psychological assaults against victim, repeatedly and regularly (at least once a week) and for a long time (at least 6 months) which ultimately results in employee turnover.

If an employee identifies strongly with a particular job, but later on there are unsuccessful and aggressiveinteractions with the supervisor, then more negative effects may riseas a result (Thoits, 1991). As a reaction of abusive supervision, employees feel decreased attachment/ commitment to the organization; they engage themselves in potentially damaging behaviors towards the organizations, such as shirking, theft, sabotage etc., (Tepper, Henle, Lambert, Giacalone, $\&$ Duffy, 2008). They undergomental and health issues such as anxiety, depression (Spector,\&Jex, 1998), and intentionally perform poorly (Mitchell \& Ambrose, 2007), which causes the poor interpersonal relationship (Inness, Barling, \& Turner, 2005). It also provokes stronger intentions of abused employees to quit the organization to retaliate against perceived supervisor's abusive behavior (Tepper et al., 2009).

Perceptions of interpersonal conflict are related to hostile work environment, job satisfaction,stress, 
and job withdrawal as well (Donovan, Drasgow\& Munson, 1998), but sometimes interpersonal conflict can be defined as direct competition over resources (Devall\& Harry, 1981) or physical incompatibilities among employees or between boss and employee (Bury, Holland\& McEwen, 1983).It is also reported that employees who work for longer hours in a hostile work environmentare more likely to experience workplace conflict, which, in-turn, lead to the poor interpersonal relations at workplace (Markel \&Frone, 1998). This is why highlighting various conflict indicators is very essential as it identifies specific problems that may divert management attention towards various conflict handling styles (Vaske, Needham \& Cline, 2007).

The impact of interpersonal interaction has not been explored extensively in literature (Venkataramani \& Dalal, 2007). It is strongly debatable that interpersonal interactions of employees with their supervisor is an important activity of everyday work life, since the job performance of employees is also based on the quality of interpersonal relationships they have with their supervisor (Wei \& Si, 2013). When subordinates experience poor leader-employee relations, they reciprocate with negative behaviors such as workplace deviance and poor interpersonal relationship (Greenberg $\&$ Scott, 1996). One of the most important things an organization can do to protect their employees as well as themselves is to ensure a safe organization where abuse and rudeness should be minimized on earlier basis (Johnson \&Indvik, 2001). On the basis of above literature our first hypothesis is:

\section{Hypothesis 1. Abusive supervision is positively associated with interpersonal conflict.}

\section{Breach of Psychological Contract as a Mediator between Abusive Supervision and Interpersonal Conflict}

The Psychological Contract can be defined as psychological promise between the employee and the organization. It refers to unwritten set of expectations of the employment relationship in addition to the formal and written employment contract. It is a cognitive model which compose the terms and exchange agreement between the employee and the employer (Rousseau, 1998). The concept of psychological contract was introduced into the management field in $60 \mathrm{~s}$ of the 20th century. Argyris (1960), an organizational psychologist, used the world "Psychological Work Contract" for the first time to explain the relationship between boss and subordinates in his book "Understanding Organizational Behavior". According to "Levinson", the father of psychological contract, the psychological contract is the combination of the implicit and unwritten mutual expectations between employees and organization (Zhang \& Huang, 2009).

Breach of psychological contract can be defined as unmet expectations of the individuals resulting from a series of unfavorable events. When subordinates perceive that the organization fails to fulfill its responsibilities and/or the organization does not give attention towards the well-being of employees, they experience breach of psychological contract (Robinson \& Morrison, 1995). In most of the cases there are major differences in supervisor's and subordinate's perceptions of psychological contract fulfillment on the basis of salary, advancement opportunities, and a desirable employment relationship (Lester, Turnley, Bloodgoog,\&Bolino, 2002). The subordinate's perception of breach of psychological contract is associated with lower levels of organizational commitment and lower supervisor's ranking of task performance(Lester et al., 2002).

Rousseau (1995) argued that promissory beliefs act as the base of employment relationships. Psychological contracts arise when employees develop expectations that lead to mutual obligations between individual employees and their supervisors (Arshad\&Sparow,2010). A high quality social exchange relationship between subordinates and supervisors reduce the possibility of breach of psychological contract (Son, 2014) whereas abusive supervision results in negative emotions such as disloyalty, anger, bitterness, shock, insecurity, loss of trust, and disappointment (Morrison \& Robinson, 1997).

The consequences of breach of psychological contract escort to the feelings of violation in the employees (Robinson \& Morrison, 2000). Psychological contracts are ever changing due to continued change in the external environment. Psychological contracts are based on mutual trust, and betrayal by supervisor tends to evoke the strong emotional reactions by the employees. When an employee perceives that his/her organization has failed to perform the administrative obligations, then it results in breach of psychological contract, which ultimately leads to interpersonal conflict (Bunderson, 2001).

When supervisors abuse their employees, psychological contract breach occurs (Wu \& Hu,2009). This aggravates the situation and employees respond with behaviors such as disrespect for the supervisor, non-compliance of ethical codes of conduct, and other behavioral patterns which results in poor interpersonal relation between supervisor and employees(Rousseau, 1989). Broken promises produce anger and eliminate trust in the relationship and sometimes violation of the verbal psychological contract can be even more harmful than breaking the formal agreement (Guest, 1998; Rousseau, 
1995). Sometimes it results in poor organizational level performance (Turnley, Bolino, Lester, \& Bloodgood, 2003). On the basis of above literature second hypothesis of the study is;

\section{Hypothesis 2. Breach of Psychological contract mediates the relationship between Abusive Supervision and Interpersonal conflict.}

\section{Moderating Role of Locus of Control}

Locus of control can be defined as the extent to which an employee expects reinforcement for behavior of other party to be under personal, i.e., internal locus of control verses impersonal i.e., external locus of control (Lefcourt, 1992). The concept of locus of control was given by Rotter (1966), who had also developed scales for internal and external locus of control to measure employee's differences in causal perceptions (Rose\& Medway, 1981). Individuals having internal locus of control react differently across situations than the individuals who have external locus of control (Mitchell, Smyser, \& Weed, 1975; Runyon, 1973). Internal locus of control is found to be an indicator of success for entrepreneurs, because internals believe that success and fortune is within the range of their personal control; whereas, externals believe that their lives are controlled by external environment, such as destiny, luck, or power etc. (Begley \& Boyd, 1987).

Both Internals and externals prefer different styles of supervision. Internals prefer participative supervision approaches; whereas, externals prefer directive supervision approaches. So, how the employees will be treated in an organization depends upon whether supervisorfollows participative approach or directive approach(Harpin\& Sandier, 1979). What style of supervision should be adopted also depends upon the task or organizational demands, e.g., directive style should be adopted for the tasks that require close coordination. Similarly, participative style is more suitable for tasks that require initiative and independent actions(Harpin\& Sandier, 1979).

People who have control over outside factors are said to have an external locus of control and are termed externals. Those who attribute control of events to themselves are said to have internal locus of control and are termed as internals (Spector,1982).Employees who experience more positive emotions respond favorably to situations assigned to them; whereas, those having more experience of negative emotions are less likely to respond positively to the particular situations (Larsen \&Ketelaar, 1991).Locus of control has also been frequently discussed in literature in association with teachers (Guskey\&Passaro, 1994). It is an important psychological attribute which affects the teachers' perceptions related to their environment and job performance (Spector, 1982).

Teachers with internal locus of control consider that the success and failure of an event is more associated with their own behaviors (Cheng, 1994), andthey adopt treatment strategy for the adjustment of emotions (Friedman, Lehrer, \& Stevens, 1983). On the other hand, teachers with external locus of control cannot control their emotions at workplace. They respond more vigorously towards abusive behaviors of supervisors, and also show low organizational commitment (Friedman, Lehrer, \& Stevens, 1983). Locus of control strengthens the relationship between abusive supervision and employees' counterproductive work behavior towards the organization (Wei \& Si, 2013). Instead of self-control, if abusive supervision prevails in the organization, then it strongly influences the interpersonal interaction of subordinates with the supervisor, and also subordinate's behavior towards the organization (Wei \& Si, 2013).On the basis of above literature third hypothesis is:

\section{Hypothesis 3. Locus of control moderates the relationship between Abusive Supervision and Interpersonal Conflict.}

\section{THEORETICAL FRAMEWORK}

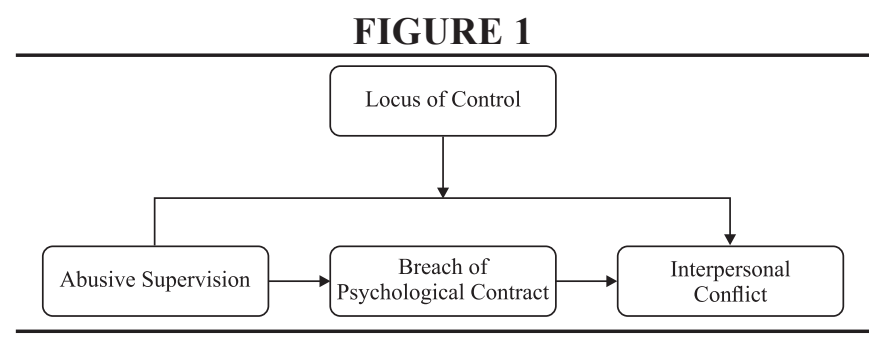

\section{METHODOLOGY}

The population included faculty members of the schools, colleges and universities working inthe institutes of Rawalpindi, Islamabad, Lahore andKarachi. About three hundred and fifty (350) questionnaires were distributed among different teachers of schools, colleges and universities of these four cities. Responses of 272 respondents were used for data analysis, making the response rate as $85 \%$.

\section{INSTRUMENTATION}

Following instruments were used:

\section{Abusive Supervision}

Abusive Supervision was measured using 
questionnaire developed by Tepper, (2000)using a 5-point likert scale. The scale reliability was 0.70 . The cronbach's alpha is 0.89 . Some of the sample items are, "My boss remind me of my past mistakes and failure." "My boss doesn't give me credit for job requiring a lot of effort." "My boss blames me to save his/her embarrassment."

\section{Interpersonal Conflict}

Interpersonal conflict was measured using a questionnaire developed by Doucet, Poitras, and Chênevert (2009) using a 5-point likert scale. The scale reliability was 0.81 . The cronbach's alpha is 0.74 . Some of the sample items are; "There are many conflicts relating to work ideas." "There are often differences in opinion regarding what should be done."

\section{Breach of Psychological Contract}

Breach of Psychological contract was measured using the questionnaire developed by Robinson and Morrison (2000) using a 5-point likert scale. The scale reliability was 0.91 .The cronbach's alpha is 0.73 . Some of the samples are; "I feel a great deal of anger towards my organization." "I feel betrayed by my organization."

\section{Locus of Control}

Locus of controlwas measured using thequestionnaire developed by Spector (1988) using a 5-point likert scale. The 16-item Work Locus of Control (WLOC) was used to measure locus of control orientation, with 8 items to measure internality and 8 items to measure externality. The scale reliability is 0.79 . The cronbach's alpha is 0.77 . Some of the samples are; "Getting the job you want is mostly a matter of luck." "Making money is primarily a matter of good fortune." "Promotions are usually a matter of good fortune."

\section{RESULTS}

\section{Correlation Analysis}

Correlation analysis show that there is a significant and positive correlation between abusive supervision and interpersonal conflict $(\mathrm{r}=.165, \mathrm{p}<0.01)$. However there is no significant relation between abusive supervision and breach of psychological contract ( $\mathrm{r}$ $=.030, \mathrm{p}>0.05)$; whereas, breach of psychological contract has shown significant and positive correlation with interpersonal conflict $(\mathrm{r}=.159, \mathrm{p}<0.01)$. Further analysis show that the correlation between abusive supervision and locus of control is negative and significant $(\mathrm{r}=-.028, \mathrm{p}<0.01)$, whereas, locus of control has significant negative correlation with interpersonal conflict $(\mathrm{r}=-0.158, \mathrm{p}<0.01)$. The following table (Table 1) shows the correlation analysis of the variables.

\section{Regression Analysis}

Regression analysis helps to determine the predictive power of a predictor variable for the dependent variable, and to measure the extent to which one variable cause variance in the other. The acceptance or rejection of hypotheses is based on the results of regression.

Table 2 indicates the regression results of abusive supervision and its effect on interpersonal conflict. A linear regression analysis was conducted to evaluate how well abusive supervision predicts interpersonal conflict. The demographics were controlled in the first step and abusive supervision was added in the second step to check the relationships. According to the table, there is a significant and positive relationship between abusive supervision (IV) and interpersonal conflict (DV) with $\beta=0.165^{* *}(p<0.01)$ that indicates the acceptance of first Hypothesis.

\section{Mediation Analysis}

Hypothesis 2 was based on the mediation analysis. Hypothesis 2 of the study predicts that Psychological contract breach is a possible mediator between the relationship of abusive supervision and interpersonal conflict. In order to test hypothesis 2 , mediation analysis was carried out through Hayes (2013) process macro by using model 4.

TABLE 1

Mean, Standard Deviation, and Correlation

\begin{tabular}{|c|c|c|c|c|c|c|c|}
\hline & Variables & Mean & S.D. & 1 & 2 & 3 & 4 \\
\hline 1 & Abusive Supervision & 2.24 & 0.78 & 1 & & & \\
\hline 2 & Interpersonal Conflict & 2.60 & 0.68 & $.165 * *$ & 1 & & \\
\hline 3 & Breach of Psychological Contract & 3.44 & 0.52 & .030 & $.159 * *$ & 1 & \\
\hline 4 & Locus of Control & 3.41 & 0.50 & $-.028 * *$ & $-.158 * *$ & $.01 * *$ & 1 \\
\hline
\end{tabular}

$N=272 .{ }^{*} p<0.05,{ }^{* *} p<0.01,{ }^{* * *} p<0.001$, Control variables: Age, Gender, Tenure, and Qualification 
TABLE 2

Hierarchical Regression Analysis for Determinants of Abusive Supervision

\begin{tabular}{lccc}
\hline Predictor & $\begin{array}{c}\text { Interpersonal } \\
\text { Conflict } \\
\boldsymbol{\beta}\end{array}$ & $\mathbf{R}^{\mathbf{2}}$ & $\mathbf{\Delta R}^{2}$ \\
\hline Independant & & & \\
Variable & & & \\
Step 1 & & & \\
Control & & 0.22 & \\
variables & & & \\
Step 2 & & & \\
Abusive & $0.165^{* *}$ & 0.046 & $0.024 * *$ \\
Supervision & & & \\
\hline
\end{tabular}

The number of bootstrap re-samples was taken as 5000 whereas the bootstrap results were tested at $95 \%$ confidence interval. Age, gender, tenure, and qualification were taken as control variables. Table 3 demonstrates the results of hypothesis 2 .

From Table 3, it can be observed that the indirect effect of Abusive supervision on Interpersonal conflict through breach of psychological contract has the upper and lower limits of 0.25 and -0.013 respectively. As both signs of upper limit and lower limit are opposite to each other, so zero is present in the $95 \%$ confidence interval which shows that mediation does not exist. On the basis of above results, it can be concluded that psychological contract breach doesn't mediate the relationship between abusive supervision and interpersonal conflict.

\section{Moderation Analysis}

In order to test hypothesis 3 , which proposed the moderating role of locus of control in the relationship of abusive supervision and interpersonal conflict, model 1 from process Macro Hayes (2013) was used. Demographics variables i.e. age, gender, tenure, and qualification were controlled. Following table shows the results of moderation analysis in which the number of bootstrap re-samples was 5000 and bootstrap results were tested at $95 \%$ confidence interval.

According to the Table 4, bootstrap values show lower and upper limits of -0.519 and -0.156 and zero is not present in the $95 \%$ confidence interval. This shows that locus of control moderates the relationship between abusive supervision and interpersonal conflict. The negative sign indicates that moderator change the direction of the relationship such that if locus of control is high then the relationship between abusive supervision and interpersonal conflict would be weakened. Hence, it fully supports the 3 rd hypothesis.

\section{DISCUSSION}

The first hypothesis proposed that abusive supervision is positively associated with interpersonal conflict. This hypothesis was accepted which shows that abusive supervision in an education institute intensifies the interpersonal conflict.

TABLE 3

Mediation Analysis

\begin{tabular}{|c|c|c|c|c|c|c|c|c|c|c|}
\hline \multirow[t]{2}{*}{ DV } & \multicolumn{2}{|c|}{$\begin{array}{c}\text { Effect of IV on M } \\
\text { (a path) }\end{array}$} & \multicolumn{2}{|c|}{$\begin{array}{c}\text { Effect of } M \text { on DV } \\
\text { (b path) }\end{array}$} & \multicolumn{2}{|c|}{$\begin{array}{l}\text { Total effect of IV } \\
\text { on DV (c path) }\end{array}$} & \multicolumn{2}{|c|}{$\begin{array}{c}\text { Direct effect of IV } \\
\text { on DV (c' path) }\end{array}$} & \multicolumn{2}{|c|}{$\begin{array}{l}\text { Bootstrap Results } \\
\text { for Indirect effects }\end{array}$} \\
\hline & $\beta$ & $\mathbf{t}$ & $\boldsymbol{\beta}$ & $\mathbf{t}$ & $\beta$ & $\mathbf{t}$ & $\beta$ & $\mathbf{t}$ & $\begin{array}{c}\text { LL } 95 \% \\
\text { CI }\end{array}$ & $\begin{array}{c}\text { UL } 95 \% \\
\text { CI }\end{array}$ \\
\hline $\mathrm{IC}$ & 0.20 & 0.496 & $0.205^{* *}$ & 2.603 & $0.145 * *$ & 2.750 & $0.141 * *$ & 2.699 & -.013 & 0.25 \\
\hline
\end{tabular}

$N=272, * p<0.05, * * p<0.01, * * * p<0.001$, Control variable: age, No. of bootstrap resample $=5000$

$* I V=$ Abusive Supervision, DV=Interpersonal Conflict (IC), $M=$ Breach of Psychological Contract

TABLE 4

Moderation Analysis

\begin{tabular}{|c|c|c|c|c|c|c|c|c|}
\hline \multirow[t]{2}{*}{ DV } & \multicolumn{2}{|c|}{ Effect of IV on DV } & \multicolumn{2}{|c|}{ Effect of Mod on DV } & \multicolumn{2}{|c|}{$\begin{array}{c}\text { Effect of IVxMod on } \\
\text { DV }\end{array}$} & \multicolumn{2}{|c|}{$\begin{array}{l}\text { Bootstrap Results for } \\
\text { Indirect effects }\end{array}$} \\
\hline & $\beta$ & $\mathbf{t}$ & $\beta$ & $\mathbf{t}$ & $\boldsymbol{\beta}$ & $\mathbf{t}$ & $\begin{array}{c}\text { LL 95\% } \\
\text { CI }\end{array}$ & $\begin{array}{c}\text { UL } 95 \% \\
\text { CI }\end{array}$ \\
\hline $\mathrm{IC}$ & $.968 * * *$ & 4.350 & $1.318^{* * *}$ & 4.043 & $-0.337 * * *$ & 3.656 & -0.519 & -0.156 \\
\hline
\end{tabular}


The present study is consistent with the literature that abusive supervision gives rise to aggressive workplace environment.

In the education sector of Pakistan, the rude and offensive behavior of Principal/Head of institute/ Supervisor toward teachers result in cold war between them, and it also intensifies the feeling of retaliation, which, in turn, causes the interpersonal conflict. Interpersonal conflicts between principal and teachers effects the teachers in the form of frustration, irritation, and annoyance. As a result, such teachers retaliate by engaging themselves in abusive behavior with their colleagues as well (Kisamore, Jawahar, Liguori, Mharapara, \& Stone, 2010). They may utter bitter words in annoyance and frustration especially to the most appreciated colleagues. This intensifies the negative social interactions among the colleagues in the long run. Interpersonal incompatibility and all these factors increase the interpersonal conflict (Jehn\&Mannix, 2001). This results in poor interpersonal relationship with the other employees (Bies\&Tripp, 1995).

The second hypothesis was that breach of psychological contract mediates the relationship of abusive supervision and interpersonal conflict. According to the results, this hypothesis was rejected. There may be many reasons for it. The cultural dimension is an important phenomenon which can't be ignored (Hofstede, 1993). In Pakistan, there is a high level of power distance between the boss and the employee. Also, there is an established trend that boss is at a high rank, so he/she has full authority to behave in a way he/she likes. Abusive behavior of boss/principal is not something which is unexpected by teachers. What kind of tone or words a boss uses to treat his/ her employees (polite or abusive) depends on his/her choice. So, psychological contract of employeesis not associated with abusive supervision, which doesn't let the employees to think that breach has been committed by their boss.

Moreover, in Pakistan, the level of unemployment is very high $(8.3 \%)$. So employees'breach of psychological contract is more associated with attractive salary packages and other benefits like incentives, bonuses and increments etc., offered by organization, and they are less concerned about other factors such as abusive behavior of boss (Lester et al., 2002). Moreover, due to very few employment opportunities, the teachers in education sector have no other option but to bear the abusive behavior of boss, and they continue to work there for the sake of money. Theseare the reasons why the mediation was not confirmed.

The third hypothesis of the study was that locus of controlmoderates the relationship of abusive supervision and interpersonal conflict. This hypothesis was accepted and it is consistent with various past studies. Most of the teachers in Pakistan have internal locus of control. They can better maintain the interpersonal relationships (Wei \& Si, 2013), and if the boss abuse them, they think that they were inefficient in performing the due tasks. So, they don't perceive those comments as harsh or inappropriate and consider themselves responsible for the situation. Such teachers use the treatment strategy for the adjustment of emotions (Friedman, Lehrer, \& Stevens, 1983) and they have ability to handle stress in general life and at workplace (Spector, Cooper, Sanchez, O'Driscoll, \& Sparks, 2002).The study also confirms that the employees having internal locus of control can better control the organizational work settings, operating procedures, work assignments, working conditions, work scheduling, organizational policy and, they also have tendency to maintain the effective social relationships with the supervisor and colleagues as well (Spector, 1982).

\section{CONCLUSION}

On the basis of the above discussion and considering the fact that the relationship of variables is tested in Pakistani context, it is concluded that most of the education sector is facing abusive supervision which causes the negative effect on the interpersonal relationship of teachers with supervisor and with colleagues as well.Unfortunately, supervisors in the education sector feel free to abuse their subordinates at any time without considering its outcomes. They feel themselves righteous in selecting an abusive tone for handling different complex workplace issues. The teachers who face abusive behavior of supervisor on frequent basis release their frustration and anxiety by either abusing their colleagues or mistreating their students. It is also concluded that psychological contract of teachers is much more associated with other attractive packages offered by organization instead of attitude of boss towards them than other factors. Moreover, employees with the internal locus of control can make better adjustments against abusive supervision, and it can reduce the chances of emerging interpersonal conflict between subordinates as compared to employees with external locus of control.

\section{Limitations, Recommendations and Future Research Directions}

Despite significance of the study and its results, there are few limitations of the study i.e., the study comprises of four major cities of Pakistan i.e. Rawalpindi, Islamabad, Lahore, and Karachi. Due to constraint of time and resources, the present study does not include 
data from teachers of other cities and especially from rural and backward areas of Pakistan which may have given different results. Also, the study includes the common method technique of data collection that is through survey questionnaires; however, detailed interviews with faculty members would have provided a more in-depth analysis.

The growth of education sector is not possible without having positive interpersonal relationships between supervisor and teachers. The growth of a nation greatly lies on the growth of its education sector. So, it is recommended that the supervisor should act more like leaders rather than just bosses. Supervisors cannot achieve organization's objectives without having effective interpersonal relationships with the teachers. The supervisors must be given trainings and guidelines about emotional management and how to treat the teachers for having the favorable interpersonal relationships. There is a dire need to create awareness among supervisors that there can be other ways to treat teachers for obtaining the positive outcomes. The study has tested the model in the education sector of Pakistan. The future researchers can test the same model in other sectors i.e. banking sector, Telecom sector and hospitality sectors etc.

The study has discussed the model in Pakistani culture. With the change of cultural context, the studymay exhibit notable variations, so the future researchers can test the same model in the other dimensions of culture. It is suggested that seminars and awareness programs should be conducted to let supervisors know about the importance of effective leadership and interpersonal relationships. The future researchers can work on other variables as moderators like organization citizenship behavior, psychological capital, perceived injustice, etc., and moderators like workplace stress, burnout etc. Similarly, the present study is cross sectional in nature. The future researchers can conduct the longitudinal study to get the more effective results. Beside abusive supervision, the future researchers should explore the other neglected issues which intensify the interpersonal conflict among employees.

\section{REFERENCES}

Amram, Y., \& Benbenishty, R. (2014).The impact of therapeutic factors on locus of control of addicts in therapeutic communities. Journal of Groups in Addiction \& Recovery, 9(4), 313-325.

Argyris, C. (1960). Understanding organizational behavior.

Arshad, R., \& Sparrow, P. (2010). Downsizing and survivor reactions in Malaysia: modeling antecedents and outcomes of psychological contract violation. The International Journal of Human

Resource Management, 21(11), 1793-1815.

Aryee, S., Chen, Z. X., Sun, L. Y., \&Debrah, Y. A. (2007). Antecedents and outcomes of abusive supervision: test of a trickle-down model. Journal of Applied Psychology, 92(1), 191.

Aryee, S., Sun, L. Y., Chen, Z. X. G., \& Debrah, Y. A. (2008). Abusive supervision and c o n t e x t u a 1 performance: The mediating role of emotional exhaustion and the moderating role of work unit structure. Management and Organization Review, 4(3), 393-411.

Baillien, E., Neyens, I., De Witte, H., \& De Cuyper, N. (2009). A qualitative study on the development of workplace bullying: Towards a three way model. Journal of Community \& Applied Social Psychology, 19(1), 1-16.

Bao, Y., Olson, B., Parayitam, S., \& Zhao, S. (2011). The effects of psychological contract violation on Chinese executives. The International Journal of Human Resource Management, 22(16), 33733392.

Barki, H., \&Hartwick, J. (2004).Conceptualizing the construct of interpersonal conflict. International Journal of Conflict Management, 15(3), 216-244.

Begley, T. M., \& Boyd, D. P. (1987). Psychological characteristics associated with performance in entrepreneurial firms and smaller businesses. Journal of Business Venturing, 2(1), 79-93.

Bies, R. J., \& Tripp, T. M. (1995). The use and abuse of power: Justice as social control. Organizational politics, justice, and support: Managing social climate at work, 131-145.

Bunderson, J. S. (2001). How work ideologies shape the psychological contracts of professional employees: Doctors' responses to perceived breach. Journal of Organizational Behavior, 22(7), 717-741.

Bury, R. L., Holland, S. M., \& McEwen, D. N. (1983). Analyzing recreational conflict Understanding why conflict occurs is requisite to managing that conflict. Journal of Soil and Water Conservation, 38(5), 401-403.

Cassar, V., \& Briner, R. B. (2011). The relationship between psychological contract breach and organizational commitment: Exchange imbalance as a moderator of the mediating role of violation. Journal of Vocational Behavior, 78(2), 283-289.

Cheng, Y. C. (1994). Locus of control as an indicator of Hong Kong teachers' job attitudes and perceptions of organizational characteristics. The Journal of Educational Research, 87(3), 180188.

De Dreu, C. K., \&Weingart, L. R. (2003). Task versus relationship conflict, team performance, and team member satisfaction: a meta-analysis. Journal of 
applied Psychology, 88(4), 741.

Devall, B., \& Harry, J. (1981). Who hates whom in the great outdoors: The impact of recreational specialization and technologies of play. Leisure Sciences, 4(4), 399-418.

Donovan, M. A., Drasgow, F., \& Munson, L. J. (1998). The Perceptions of Fair Interpersonal Treatment Scale: development and validation of a measure of interpersonal treatment in the workplace. Journal of Applied Psychology, 83(5), 683.

Doucet, O., Poitras, J., \&Chênevert, D. (2009).The impacts of leadership on workplace conflicts. International Journal of Conflict Management, 20(4), 340-354.

Einarsen, S. (1999). The nature and causes of bullying at work. International Journal of Manpower, 20(1/2), 16-27.

Findley, M. J., \& Cooper, H. M. (1983). Locus of control and academic achievement: a literature review. Journal of Personality and Social Psychology, 44(2), 419.

Friedman, G. H., Lehrer, B. E., \& Stevens, J. P. (1983). The effectiveness of self-directed and lecture/ discussion stress management approaches and the locus of control of teachers. American Educational Research Journal, 20(4), 563-580.

Greenberg, J., \& Scott, K. S. (1996). Why do workers bite the hands that feed them? Employee theft as a social exchange process.

Guest, D. E. (1998). Is the psychological contract worth taking seriously? Journal of Organizational Behavior, 19(s 1), 649-664.

Guskey, T. R., \&Passaro, P. D. (1994). Teacher efficacy: A study of construct dimensions. American Educational Research Journal, 31(3), 627-643.

Harpin, P. M., \& Sandler, I. N. (1979). Interaction of sex, locus of control, and teacher control: Toward a student-classroom match. American Journal of Community Psychology, 7(6), 621-632.

Harvey, P., Harris, K. J., \&Martinko, M. J. (2008).The mediated influence of hostile attributional style on turnover intentions. Journal of Business and Psychology, 22(4), 333-343.

Harvey, P., Stoner, J., Hochwarter, W., \&Kacmar, C. (2007).Coping with abusive supervision: The neutralizing effects of ingratiation and positive affect on negative employee outcomes. The Leadership Quarterly, 18(3), 264-280.

Hayes, A. F. (2013). Introduction to mediation, moderation, and conditional process analysis: A regression-based approach. Guilford Press.

Hofstede, G. (1993). Cultural constraints in management theories. The Academy of Management Executive, 7(1), 81-94.
Inness, M., Barling, J., \& Turner, N. (2005). Understanding supervisor-targeted aggression: a within-person, between-jobs design. Journal of Applied Psychology, 90(4), 731.

Jehn, K. A. (1995). A multi method examination of the benefits and detriments of intragroup conflict. Administrative Science Quarterly, 256-282.

Jehn, K. A., \&Mannix, E. A. (2001). The dynamic nature of conflict: A longitudinal study of in $\mathrm{tr}$ a g r o u p conflict and group performance. Academy of Management Journal, 44(2), 238251.

Johnson, P. R., \& Indvik, J. (2001). Rudeness at work: Impulse over restraint. Public Personnel Management, 30(4), 457-465.

Kisamore, J. L., Jawahar, I. M., Liguori, E. W., Mharapara, T. L., \& Stone, T. H. (2010). Conflict and abusive workplace behaviors: The moderating effects of social competencies. Career Development International, 15(6), 583-600.

Kotlyar, I., \&Karakowsky, L. (2006). Leading conflict? Linkages between leader behaviors and group conflict. Small Group Research, 37(4), 377-403.

Larsen, R. J., \&Ketelaar, T. (1991).Personality and susceptibility to positive and negative emotional states. Journal of Personality and Social Psychology,61(1), 132.

Lefcourt, H. M. (1992). Durability and impact of the locus of control construct. Psychological Bulletin, 112(3), 411

Lester, S. W., Turnley, W. H., Bloodgood, J. M., \&Bolino, M. C. (2002). Not seeing eye to eye: Differences in supervisor and subordinate perceptions of and attributions forpsychological contract breach. Journal of Organizational Behavior, 23(1), 39-56.

Leymann, H. (1990). Mobbing and psychological terror at workplaces.Violence andvictims, 5(2), 119-126.

Leymann,H.(1992).Leymanninventory ofpsychological terror.Violen, Karlskrona.

Leymann, H., \&Gustafsson, A. (1996).Mobbing at work and the development of post-traumatic stress disorders. European Journal of Work and Organizational Psychology, 5(2), $251 \quad 275$.

Markel, K. S., \& Frone, M. R. (1998). Job characteristics, work-school conflict, and school o u t c o m e s among adolescents: Testing a structural model. Journal of Applied Psychology, 83(2), 277.

McKenna, B., Smith, N., Poole, S. and Coverdale, J: 'Horizontal violence, experiences of registered Nurses in their first year of practice', Journal of Advanced Nursing, 2003, 42, 1, 90-96.

Mitchell, M. S., \& Ambrose, M. L. (2007).Abusive supervision and workplace deviance and the moderating effects of negative reciprocity beliefs. 
Journal of Applied Psychology, 92(4), 1159.

Mitchell, T. R., Smyser, C. M., \& Weed, S. E. (1975). Locus of control: Supervision and work satisfaction. Academy of Management Journal, 18(3), 623-631.

Morrison, E. W., \& Robinson, S. L. (1997). When employees feel betrayed: A model of how psychological contract violation develops. Academy of management Review, 22(1), 226-256.

Pondy, L. R. (1967). Organizational conflict: Concepts and models. Administrative Science Quarterly, 296-320.

Robinson, S. L., \& Morrison, E. W. (1995). Psychological contracts and OCB: The effect of unfulfilled obligations on civic virtue behavior. Journal of Organizational Behavior, 16(3), 289-298.

Robinson, S. L., \& Morrison, E. W. (2000). The development of psychological contract breach and violation: A longitudinal study. Journal of Organizational Behavior, 21(5), $525 \quad 546$.

Rose, J. S., \& Medway, F. J. (1981).Measurement of teachers' beliefs in their control over student outcome. The journal of Educational Research,74(3), 185-190

Rotter, J. B. (1966). Generalized expectancies for internal versus external control of reinforcement. Psychological Monographs: General and Applied,80(1), 1.

Rotter, J. B. (1971).Generalized expectancies for interpersonal trust. American Psychologist, 26(5), 443.

Rousseau, D. (1995). Psychological contracts in organizations: Understanding written and unwritten agreements.

Rousseau, D. M. (1989).Psychological and implied contracts in organizations. Employee Responsibilities and Rights Journal, 2(2), 121139.

Rousseau,D.M.(1998).The'problem'ofthe psychological contract considered. Journal of Organizational Behavior, 19(s 1), 665-671.

Runyon, K. E. (1973). Some interactions between personality variables and management styles. Journal of Applied Psychology, 57(3), 288.

Skogstad, A., Torsheim, T., Einarsen, S., \&Hauge, L. J. (2011). Testing the work environment hypothesis of bullying on a group level of analysis: Psychosocial factors as precursors of observed workplace bullying. Applied Psychology, 60(3), 475-495.

Son, S. Y. (2014). The Effects of Perceived Organizational Support and Abusive Supervision on employee's turnover intention: the mediating roles of psychological contract and emotional exhaustion. World academy of Science, Engineering and Technology, International
Journal of Social, Behavioral, Educational, Economic and Management Engineering, 8(4), 1105-1111.

Spector, P. E. (1982). Behavior in organizations as a function of employee's locus of control. Psychological Bulletin, 91(3), 482.

Spector, P. E. (1988). Development of the work locus of control scale. Journal of Occupational Psychology, 61(4), 335-340.

Spector, P. E., \&Jex, S. M. (1998). Development of four self-report measures of job stressors and strain: Interpersonal Conflict at Work Scale, Organizational Constraints Scale, Quantitative Workload Inventory, and Physical Symptoms Inventory. Journal of Occupational Health Psychology,3(4), 356.

Spector, P. E., Cooper, C. L., Sanchez, J. I., O'Driscoll, M., Sparks, K., Bernin, P., ...\& Miller, K. (2002). Locus of control and well-being at work: how generalizable are western findings? Academy of Management Journal,45(2), 453-466.

Tedeschi, J. T., \& Norman, N. M. (1985).A social psychological interpretation of displaced aggression. Advances in Group Processes, 2, 2956.

Tepper, B. J. (2000). Consequences of abusive supervision. Academy of Management Journal, 43(2), 178-190.

Tepper, B. J., Carr, J. C., Breaux, D. M., Geider, S., Hu, C., \& Hua, W. (2009). Abusive supervision, intentions to quit, and employees' workplace deviance: A power/dependence analysis. Organizational Behavior and Human Decision Processes, 109(2), 156-167.

Tepper, B. J., Duffy, M. K., Hoobler, J., \& Ensley, M. D. (2004).Moderators of the relationships between coworkers' organizational citizenship behavior and fellow employees' attitudes. Journal of Applied Psychology, 89(3), 455.

Tepper, B. J., Henle, C. A., Lambert, L. S., Giacalone, R. A., \& Duffy, M. K. (2008). Abusive supervision and subordinates' organization deviance. Journal of Applied Psychology, 93(4), 721.

Thoits, P. A. (1991). On merging identity theory and stress research. Social Psychology Quarterly, 101112 .

Thomas, Kenneth W. "Conflict and conflict management: Reflections and update." Journal of Organizational Behavior 13.3 (1992): 265-274

Turnley, W.H., Bolino, M.C., Lester, S. W., \&Bloodgood, J. M. (2003).The impact of psychological contract fulfillment on the performance of in-role and organizational citizenship behaviors. Journal of management, 29(2), 187-206.

Vaske, J. J., Needham, M. D., \& Cline, R. C. (2007). 
Clarifying interpersonal and social values conflict among recreationists. Journal of Leisure Research, 39(1), 182.

Venkataramani, V., \& Dalal, R. S. (2007). Who helps and harms whom? Relational antecedents of interpersonal helping and harming in organizations. Journal of Applied Psychology, 92(4), 952.

Wayne, S. J., Hoobler, J., Marinova, S. V., \& Johnson, M. M. (2008, August). Abusive behavior: Trickledown effects beyond the dyad. In Academy of Management Proceedings (Vol. 2008, No. 1, pp. 1-6). Academy of Management.

Wei, F., \& Si, S. (2013). Psychological Contract Breach, Negative Reciprocity, and Abusive Supervision: The Mediated Effect of Organizational Identification. Management and Organization Review, 9(3), 541561
Wei, F., \& Si, S. (2013).Tit for tat? Abusive supervision and counterproductive work behaviors: The moderating effects of locus of control and perceived mobility. Asia Pacific Journal of Management, 30(1), 281-296.

$\mathrm{Wu}, \mathrm{T}$. Y., \& $\mathrm{Hu}$, C. (2009).Abusive supervision and employee emotional exhaustion dispositional antecedents and boundaries. Group \& Organization Management, 34(2), 143-169.

Zellars, K. L., Tepper, B. J., \& Duffy, M. K. (2002). Abusive supervision and subordinates' organizational citizenship behavior. Journal of Applied Psychology, 87(6), 1068.

Zhang, S., \& Huang, X. (2009).An Analysis on the Recessive Drain of College Teachers in Perspective of PsychologicalContract. International Journal of Business and Management, 4(3), 126. 